$1-1-1972$

\title{
Illogicality and Roman Law
}

\author{
Alan Watson \\ University of Georgia School of Law, wawatson@uga.edu
}

PS

\section{Repository Citation}

Alan Watson, Illogicality and Roman Law (1972),

Available at: https://digitalcommons.law.uga.edu/fac_artchop/462

This Article is brought to you for free and open access by the Faculty Scholarship at Digital Commons @ University of Georgia School of Law. It has been accepted for inclusion in Scholarly Works by an authorized administrator of Digital Commons @ University of Georgia School of Law. Please share how you have benefited from this access For more information, please contact tstriepe@uga.edu. 


\title{
ILLOGICALITY AND ROMAN LAW*
}

\author{
By Alan Watson**
}

It is a commonplace that Rome's greatest contribution to the modern world is its law. Whether this is strictly true or not, Roman law is certainly the basis of the law of Western Europe (with the exception of England and Scandinavia), of much of Africa including South Africa, Ethiopia and in general the former colonies of countries in continental Europe, of Quebec and Louisiana, of Japan and Ceylon and so on. Perhaps even more important for the future is that International law is very largely modelled, by analogy, on Roman law. Just think of the perfectly serious arguments of a few years ago as to whether outer space (including the moon and planets) were res nullius or res communes and whether they were, or were not, susceptible of acquisition by occupatio. This persistence of Roman law has had undesirable consequences. First, Roman law as an academic subject has got into the hands of lawyers whose love of technicalities has frightened off classical scholars who tend not to use the legal sources. Secondly, scholars of antiquity, since Roman law is left well alone, have also been reluctant to look at other ancient legal systems.". So have lawyers since these other systems have no 'practical' value. Thirdly, following upon these but worse still, the usefulness of Roman law for later ages, coupled with its enforced isolation from other systems of antiquity, has often led to an exaggerated respect for it, and to its being regarded as well-nigh perfect, immutable, fit for all people. Many in "the Age of Reason" were ready to regard Roman law as "the Law of Reason".

Thus, Roman law is divorced from its context. Of course, in its natural setting it was not like that at all: it was not perfect, unchangeable or abstract reasoning. Bad rules, weak reasons, illogical arguments abound. Let me cite here only one extreme instance of a bad reason. The jurists Labeo and Paul agree that a slave who lacks a tooth and is sold without the defect being

* Text of a lecture delivered to the Classical Association of Scotland Meeting in Aberdeen on 1st May, 1971.

The following abbreviations are used: $\mathrm{C}=$ Codex Justiniani; $\mathrm{D}=$ Digesta Justiniani; $\mathrm{G}=$ Gai Institutiones; $\mathrm{J}=$ Justiniani Institutiones.

** Professor of Civil Law, University of Edinburgh.

1 Nonetheless in number of publications non-lawyers have contributed proportionally more-and perhaps even absolutely more - to the study of Greek and Near Eastern legal systems than to Roman law. It should also, in fairness to Roman lawyers, be said that Near Eastern law is more immediately comprehensible to the non-lawyer. 
disclosed cannot be returned to the seller as morbosus under the Aedilician Edict. They both give as a reason that many people lack teeth, that babies are born without teeth and yet they are not regarded as minus sani until teeth appear. ${ }^{2}$ But as W.W. Buckland pointed out long ago, the argument is absurd for it is equally true that babies are unable to walk. ${ }^{3}$

But I do not want to discuss here weakness of reasoning by individuals. Rather I want to look at satisfactory legal developments acceptable to all or nearly all jurists where logic or strict reasoning is set to one side, where the jurists show that they are not philosophers of an eternal pure reason but hard-headed lawyers dealing with actual situations in a real world where the result is of greater importance than the way it is obtained. Developments, that is, which illustrate the famous dictum of Oliver Wendell Holmes: "The life of the law has not been logic: it has been experience". "The instances I will speak of are all cases where, so far as the surviving evidence goes, there was no dispute; where, so to say, there was such an overwhelming desire to achieve the end result that the illogicality was either not noticed or at least not stressed.

The first instance concerns the revocation of the kind of will known as testamentum per aes et libram which was the standard will throughout the classical period. This will was an adaptation of mancipatio, the formal mode of transfer of those things known as res mancipi, and as a mancipatio it required a transferee, five witnesses and a person known as the libripens, who held a bronze scale. The transferee in this case was called the familiae emptor and he had to declare:

I declare that your property is subject to your command and under my control and, so that you can lawfully make a will in accordance with the public statute, let it have been bought to me with this bronze and brazen scale. ${ }^{5}$

He then struck the scale with a bronze piece which he gave to the testator as the symbolic price. ${ }^{6}$ Next the testator holding the tablets on which the will was written ${ }^{7}$ made a formal declaration called nuncupatio confirming the will's provisions. ${ }^{8}$ Originally the familiae emptor would be in the position of heir $^{9}$, and since mancipatio was an immediate transfer of ownership he would become owner of the testator's property at the time of the ceremony. But now,

2 Aulus Gellius, Noctes Atticae 4.2.12; D. 21.1.11.

3 "Interpolations in the Digest" (1924) 33 Yale L.J. 343 at 347.

4 The Common Law (Boston, 1881) 1.

5 Familiam pecuniamque tuam endo mandatela tua custodelaque mea esse aio, eaque, quo tu iure testamentum facere possis secundum legem publicam, hoc aere aeneaque libra esto mihi empta.

6 G. 2.104 .

7 If the will was reduced to writing, which it need not be.

8 G. 2.104. 9 Later he became a mere figurehead: G. 2.103. 
the testator might subsequently change his mind and want to revoke the will. How could this be done? The position at civil law in the early Empire, when the picture first becomes clear ${ }^{10}$, is that intention to revoke was not enough. Nor was it sufficient to destroy the tabulae of the will, even with the intention of revocation.1. The old will was revoked only when the testator made a new and valid will by a new mancipatio and nuncupatio. ${ }^{12}$ Destruction of the tabulae, it is thought by modern scholars, ${ }^{13}$ was not enough because the will's validity derived from the mancipatio and the nuncupatio, not from the continuing existence of the tabulae. This opinion is, I think, correct. Logically, though, we might have expected something else. By the mancipatio, the testator ceased to be owner of his property. Hence, for a new will, the cooperation of the familiae emptor should have been required. He should have remancipated the estate to the testator for only then would the latter be owner and so capable of disposing of it once again. But this was awkward and inconvenient and not at all helpful, and the jurists did not demand so much. ${ }^{14}$ The surviving sources record no dispute among the jurists on the requirements for revocation, and the illogicality is not pointed out. ${ }^{15}$

A second example involves the forms of manumission of slaves and the rights of patrons in the Republic. A slave might be freed by his master in three ways: by will, by manumissio vindicta, by enrolment on the census. We are concerned only with the last two.

Manumissio vindicta ${ }^{16}$ was an adaptation of the vindicatio in libertatem, the procedure by which anyone could bring an action to secure the release of a free man who was wrongly held as a slave. A master who wanted to free a slave would appear before a magistrate who had imperium, and a friend would claim that the slave was free. The master put up no defence and the magistrate declared the slave free. In manumissio censu, the owner ordered the slave to inscribe himself on the censor's list of citizens. Whether the slave then became free and a citizen at once, or only when the list was issued is

10 Though Suetonius, Divus Iulius, 83 , shows that already in the late Republic a validly made will could somehow be revoked.

11 G. 2.151 .

12 G. 2.144 .

13 E.g., M. Kaser, Das römische Privatrecht I (Munich, 1955) 578; P. Voci, Diritto ereditario romano, ii (Milan, 1963) $492 \mathrm{f}$.

14 Possibly they did once, but if so there is no trace in the sources. The possibility does not affect the point being made.

15 It is likely that this procedure for revocation was accepted at an early date. Other theoretical problems connected with the familiae emptor being regarded as ownere.g., there was no action against him if he failed to carry out the testator's instructions; and what if he died before the testator?-do not appear as practical difficulties and hence it is likely that almost from the start the testamentum per aes et libram was regarded as a true will.

16 See in general W. W. Buckland, A Textbook of Roman Law, revised by P. Stein (Cambridge, 3rd ed., 1963) 441 ff. 
not clear $^{17}$ but does not concern us. What does matter is that in neither of these modes of manumission does it appear as if a slave was freed by his master. In one it seems as if the true status of a citizen wrongly held as a slave is recognized, and in the other there is no indication that the person enrolled as a citizen was ever anything else.

A master who freed a slave became the new freedman's patronus and as such had extensive rights. ${ }^{18}$ The freedman owed him obsequium and operae (a number of days' labour) and, perhaps most important of all, on the freedman's death the patron might have extensive rights of succession. A master whose slave was freed vindicta or censu had full rights of patronage. So far as we can tell it was never even suggested that the master had not in fact freed the slave. Again the jurists reach the sensible result without apparently worrying about any illogicality. The use of a device such as manumissio vindicta or manumissio censu was essential since there was otherwise no way in which a slave could be freed during his master's lifetime.

The third instance relates to drunkenness and intention. ${ }^{19}$ As in other systems, so in Roman law, intention was of fundamental importance in many situations. Thus, for the commission of theft there had to be an intention to steal; $;^{20}$ there could be no marriage without the requisite intention of the interested parties; $;^{21}$ and in the consensual contracts of sale, hire, partnership and mandate the contract was formed as soon as agreement was reached and any absence of agreement barred the existence of the contract. ${ }^{22}$ As everyone will readily agree, extreme intoxication is able to stop the formation of intention or any agreement. British courts can provide many examples. ${ }^{23}$ Drunkenness is common now and, to judge from literary evidence, was common in Roman times (despite the ignorance of spirits), but nowhere in the Roman sources are we told of the effects of drunkenness on intention; not for theft, not for marriage, not for contract. The text which comes nearest is D. 48.19.11.2,

17 See now A. Watson, The Law of Persons in the Later Roman Republic (Oxford, 1967) $185 \mathrm{ff}$.

18 See, ibid., $226 \mathrm{ff}$.

19 For what follows see A. Watson, "Drunkenness in Roman Law" Sein und Werden im Recht; Festgabe für Ulrich von Lübtow (Berlin, 1970), $381 \mathrm{ff}$.

20 Cf. e.g., G. 3.197; D. 47.2.23. The precise nature of the animus furandi and the extent of corruption in the sources do not really concern us. But see most recently J.A.C. Thomas, "Animus furandi" (1968) 19 Iura 1; A Watson, Roman Private Law Around 200 B.C. (Edinburgh, 1971) 147.

21 Cf. e.g., D. 23.2.2; 23.2.16.2; P. Corbett, The Roman Laiv of Marriage (Oxford, 1930), 53ff; A. Watson, Persons, $41 \mathrm{ff}$.

22 Thus, in sale it is especially clear that error which was sufficiently grave stopped the contract coming into existence: e.g., D. 18.1.9; ibid., 11 ; ibid., 14.

23 Thus in England, Ruse v. Read [1949] 1 K.B; 377; [1949] 1 All E.R. 398 (incapacity to form intention to steal bicycle); in Scotland, Johnston v. Brown (1823) 2. S. 437 (incapacity during 3 whole days to form intention to marry). 
which tells us that an injury might be caused aut proposito aut impetu aut casu and to illustrate injury impetu (on the spur of the moment), as cum per ebrietatem ad manus aut ad ferrum venitur (when through drunkenness it comes to [the use of] hands or iron). Strangely enough there is in general a great scarcity of Roman legal texts on conduct influenced by alcohol or on habitual or heavy drinking-only seven in all, including that just mentioned. ${ }^{24}$ The absence of any discussion of the effect of alcohol on intention surely cannot be explained by saying that the problem did not arise in practice, and that the jurists did not think of it as a theoretical possibility. Nor because it was simply assumed that a person always intended what he did-the inability of an infant or lunatic to form an intention is continually stressed. ${ }^{25}$ The earliest case known to me of drunkenness so extreme as to exclude intention or knowledge goes back far beyond Roman times to the story of Lot and his daughters in Genesis. Thus, 19.33: "And they made their father drink wine that night: and the firstborn went in, and lay with her father; and he perceived not when she lay down, nor when she arose". We can argue from the silence of the Roman sources that intoxication-almost always a self-induced statewas not considered legally relevant and hence did not bar agreement. Presumably it was a man's own fault if he got drunk and did something foolish. ${ }^{26}$ The result might well be considered reasonable, but if the situation was as I have suggested then an obvious illogicality is involved. The aspect of greatest interest is, of course, the silence of the sources. I suspect but cannot prove that the jurists, satisfied with what seemed to be the legal position, were unwilling to reduce the proposition to writing lest that very fact invite contradiction.

The next example I wish to give also concerns intention. In developed classical law a person acquired possession of a thing only if he had the requisite degree of physical control over it and the right kind of intention to hold on to it. In the late Republic, apparently, requirements were not so strict. ${ }^{27}$ This increased stress on animus in the Empire caused problems, for instance in the acquisition of possession by infants. Thus:

An infant can rightly possess if he begins with his tutor's authority, for the infant's judgment is made good by the tutor's authority. This has been accepted on the ground of utility for otherwise an infant's acquiring possession is nonsense. A pupil, however, can acquire possession even

24 The others are, Aulus Gellius, Noctes Atticae, 4.14; D. 48.3.12pr; 24.1.4.2; ibid., 25.6 (idem); 49.16.6.7 Codex Theodosianus 3.16.1.

25 Cf. e.g., D. 9.2.5.2.; J. 1.10 pr; D. 41.2.32.2; 50.17.5.

26 Just at we are told in sale, D. 18.1.15.1: Ignorantia emptori prodest, quae non in supinum hominem cadit (Only such ignorance as does not betray negligence will avail a buyer).

27 Cf. A. Watson, The Law of Property in the Later Roman Republic (Oxford, 1968) $81 \mathrm{ff}$. 
without his tutor's authority. Likewise an infant can possess through a slave in respect of the peculium. ${ }^{28}$

An infans, we are told, can possess auctoritate tutoris. There are two extreme oddities in this. In the first place, we know that auctoritas tutoris was needed when the transaction might make the position of the pupil worse but not otherwise. $^{29}$ Now although possession did have legal consequences it would be very difficult to think of a situation-I can think of none-where possessio, as opposed to mere physical control, could have harmful consequences for the possessor. Almost always possessio brings advantages. Hence auctoritas tutoris should be irrelevant. In the second place, the function of auctoritas tutoris in other cases is not to supply an intention which is totally lacking in the pupil, but to add mature judgment to the pupil's intention. In other words it operates only when the pupil has capacity, that is, when he is infantia maior. ${ }^{30}$ Hence, auctoritas tutoris for an infans seems inappropriate. The requirement of tutoris auctoritas here is an anomalous innovation to overcome the infant's new incapacity to acquire possession. ${ }^{31}$ This time, though, Paul recognizes the illogicality of the decision which he says is utilitatis causa receptum. The argument from utilitas is often used when the jurists reach a solution which is dogmatically indefensible. ${ }^{32}$

A slave was not a legal person, and so his capacity to contract was purely derivative. W. W. Buckland says:"33 "As a slave derives his capacity from his master, it might be supposed that he could not have more than the master had. But this would have involved inconvenience, and it is clear that for a master incapable of contracting from mental or physical defect, the slave could stipulate. The rule seems illogical, but its illogicality is concealed by the fact that a slave's stipulation, as we have seen, did not require the consent or knowledge of the master." But one case seems even more illogical than the others. A slave could be a partner. The main text is D.17.2.58.3 (Ulpian 31 ad ed.). ${ }^{34}$

D. 41.2.32.2 (Paul 15 ad Sab.) Infans possidere recte potest, si tutore auctore coepit, nam judicium infantis suppletur auctoritate tutoris: utilitatis enim causa hoc receptum est, nam alioquin nullus sensus est infantis accipiendi possessionem, pupillus tamen etiam sine tutoris auctoritate possessionem nancisci potest, item infans peculiari nomine per servum possidere potest. On the text and for questions of interpolation see A. Watson, "Acquisition of Possession and Usucaption per servos et filios (1962) 78 L.Q.R. 205 at $223 \mathrm{ff}$.

20 G. $2.80-84$.

30 Cf. e.g., W.W. Buckland, Textbook, 157 ff; M. Kaser, Privatrecht i, p. 306.

31 That in the Republic it was held an infant could acquire possession without his tutor's authority appears from D. 41.2.1.3: cf. A. Watson, Property, 82f.

32 Cf. J.A. Ankum, "Utilitatis causa receptum", Symbolae M. David (Leiden, 1968), 1 ff. D. 41.2 .32 .2 is discussed at $10 \mathrm{ff}$.

33 The Roman Law of Slavery (Cambridge, 1908) 155.

34 The others are D. 17.2.18; ibid., 63.2. 
If my slave contracted a partnership with Titius and continued in it when he had been alienated, it can be said that by the alienation of the slave the first partnership was ended and also that a second was begun afresh; and likewise that an actio pro socio is available both to me and to the buyer; and similarly that an action can be given both against me and against the buyer on account of matters before the alienation, on other matters only against the buyer. ${ }^{35}$

Neither the text itself nor the fact that slaves could be socii (partners) has aroused much interest. ${ }^{36}$ The language of the text (and of the others) shows that it is the slave who enters the societas, not his master. But more than that, in the present text the situation makes it plain that it is the slave and not the master who is the socius. Otherwise the alienation of the slave would not have brought the partnership to an end so far as the former master was concerned. ${ }^{37}$ But how on earth can a slave who has no legal personality be a partner? There is no logical answer and we can say only that it was obviously convenient for the master that his slave could enter into partnership arrangements. ${ }^{38}$ Convenience triumphed.

There are at least two illogicalities in stipulations post mortem. A contract of stipulatio to be performed after the death of one of the parties was void because, says Gaius, ${ }^{39}$ "it was regarded as inelegant for an obligation to begin from the heir". Thus post mortem meam dari spondes? (Do you promise that after my death be given) and post mortem tuam dari spondes? (Do you promise that after your death be given) did not give rise to a valid contract, nor naturally did Heredi meo dari spondes? (Do you promise that to my heir be given). Neither did Pridie quam moriar dari spondes? (Do you promise that the day before I die be given) nor Pridie quam morieris dari spondes? (Do you promise that the day before you die be given) because, we are told, the day before the death cannot be told until after the death has occurred. All this so far is straightforward enough. But Gaius tells us that

35 Si servus meus societatem cum Titio coierit et alienatus in eadem permanserit, potest dici alienatione servi et priorem societatem finitam et ex integro alteram inchoatam, atque ideo et mihi et emptori actionem pro socio competere, item tam adversus me quam adversus emptorem ex his causis quae ante alienationem inciderunt dandum actionem, ex reliquis adversus emptorem solum.

36 See G. v. Beseler (1925) 45 Zeitschrift der Savigny-Stiftung für Rechtsgeschichte, Romanistische Abteilung 466; S. Solazzi (1955) 21 Studia et Documenta Historiae et Iuris, $306 \mathrm{ff}$. Interpolations suggested by these two authors do not affect us, and we need not consider them.

37 Even if the master was the socius, D. 17.2.58pr would be a totally different kind of case, and irrelevant.

38 It should perhaps be stressed again that the illogicality here is greater than in, say, sale where a slave seller could be regarded as a representative for his master, and the sale to be the master's.

39 G. 3.100 . 
Cum moriar dari spondes? (Do you promise that when I die be given) and Cum morieris dari spondes? (Do you promise that when you die be given) were valid forms and the obligation was considered to begin at the last moment of life. ${ }^{40}$ Now no sophisticated theory of formalism will explain why this case is treated differently from the others, nor is any satisfaction to be obtained by regarding nam inelegans esse visum est ab heredis persona incipere obligationem (for it appeared unreasonable that an obligation should start from the heir) in G. 3.100 as interpolated. ${ }^{41}$ The explanation, let it be said at once, has no theoretical justification, nor does Gaius give one. The easiest solution is that stipulations post mortem were void, ${ }^{42}$ the rule had obvious practical disadvantages but had been in existence so long that the effect of the usual forms could not be altered. The rather absurd form Pridie quam moriar dari spondes? has, indeed, all the appearance of an (unsuccessful) attempt to get round the invalidity. At some stage, when the jurists were more receptive to allowing the validity of such a stipulation, a fresh attempt was made with a new formulation, Cum moriar dari spondes? and it worked.

A similar explanation holds true for the second illogicality in stipulation post mortem. An adstipulatio was an accessory stipulation when the adstipulator asked the promisor, after the first stipulatio, if he promised to give him the same thing. Performance by the promisor of either the stipulatio or the adstipulatio extinguished both obligations. ${ }^{43}$ Gaius tells us that generally we use adstipulatio only when we are stipulating for something to be given to us after our death. ${ }^{44}$ The stipulation itself being post mortem creditoris is void, ${ }^{45}$ but the adstipulatio, being only post mortem of an outsider to the contract is valid. It is thus another device to make enforceable a stipulatio post mortem. But despite this apparent reasonableness Zimmern pointed out long ago ${ }^{46}$ a theoretical, dogmatical difficulty. The adstipulatio is an accessory to, and dependent upon, the stipulatio. The stipulatio is void, hence so should be the adstipulatio.

A fascinating branch of Roman law is that known as postliminium. ${ }^{47}$ This

3.100. The literature on the text is enormous.

Cf. e.g., recently, S. Solazzi, "Sull" obbligazione a termine iniziale" (1950) 1 Iura 34 at 52, and the authors he cites; contra, e.g., J. Van Oven, "Gaius 3. 158: mandatum post mortem mandantis" (1956) 48 Eos 528, S. Di Paola, Contributi ad una teoria della invalidità $e$ della inefficacia in diritto romano (Milan, 1966) p. 21 n. 46.

42 No need here to explain why.

43 Cf. G. 3.110-114.

$44 \mathrm{G}, 3.117$ 45 G. 3.117.

46 Archiv für die civilistische Praxis iv (1821), 240; see more recently, V. ArangioRuiz, Il mandato in diritto romano (Naples, 1949), 148; A. Watson, Contract of Mandate in Roman Law (Oxford, 1961) 136.

47 On postliminium in general see L. Amirante, Captivitas e postliminium (Naples, 1950). 
was, basically but by no means exclusively, the right by which a Roman who had lost his citizenship, e.g., by being captured by the enemy, regained his citizenship and recovered various private rights when he returned within Roman territory as a free man. Technically, one would expect that capitis deminutio maxima, i.e., by losing his citizenship and freedom, the captive would lose all his personal rights, and that these rights would not revive simply because he returned to Rome. This was, indeed, the case with those persons not entitled to postliminium. ${ }^{48}$ The curious thing about postliminium, though, it that in classical law its effect was different on different rights. This appears most clearly in family law which is all we need look at for our purposes. Marriage was ended by capture and did not revive by postliminium. ${ }^{40}$ To this there were two exceptions; first, if both spouses were captured and returned together ${ }^{50}$ secondly, in the opinion of some, notably Julian, where a patronus was captured who had married his freedwoman. ${ }^{51}$

When a tutor legitimus or testamentarius was captured the tutela (guardianship) ended but was restored, though not retroactively, if he returned. ${ }^{52}$ Patria potestas was suspended by captivity and if the captive returned with postliminium it was as if he had never been a prisoner. ${ }^{53}$ No amount of ingenious hair-splitting argument will make this a logical system. The explanation really is that in each branch of family law the jurists accepted the rule which would give the most satisfactory practical result. Thus, marriage was completely ended, so that if the captive's ex-wife married someone else, the status of that union and any children born to her was not in doubt. (It should be remembered that divorce was simple and without formality and hence a new marriage between the former captive and his ex-wife would be an easy possibility). For the well-being of the pupil it was essential that a tutor be there to help him, hence captivity ended the tutelage and a fresh tutor could be appointed. But since the tutor legitimus was his nearest agnate and the tutor testamentarius the person considered by the deceased pater to be most suitable as tutor, it was appropriate that their tutela be re-established by the tutor's return. The protection of the captive's property rights made it important that his sons were not regarded as having been free from patria potestas even during his absence. ${ }^{54}$

Cf. e.g., D. 49.15.12pr; ibid., $17 ; 49.16 .5 .6$.

Cf. e.g., D. $24.2 .1 ; 49.15 .12 .4$; ibid., 14.1 .

C. $8.50(51) .1$; D. 49.15 .25 .

D. 23.2.45.6. For these exceptions see above all A. Watson "Captivitas and matrimonium" (1961) 29 Tijdschrift voor Rechtsgeschiedenis 243.

G. 3.187 ; D. 27.3.7.1; 27.3.8; 46.6.4.5; 26.4.3; 26.1.15; cf. L. Amirante, Captivitas, $60 \mathrm{ff}$.

G. 1.129; Gai Epitome 1.6.2; Pauli Sententiae 2.25.1; D. 14.6.1.1; 37.9.1.8; 38.6.15; 49.15.12.1; 49.15.22.2; cf. L. Amirante, Captivitas, $51 \mathrm{ff}$.

4 Of course, in each branch of family law particular problems could arise no matter what rule was adopted. 
My last example has been chosen to leave you with a problem. The famous lex Aquilia of 287 B.C. regulated the law of damage to property. Its first chapter read, and was regarded by the classical jurists as reading:

Whoever will have wrongfully killed another's male or female slave or fourfooted herd animal, whatever was the victim's highest value in that year, so much bronze let him be condemned to pay the owner. ${ }^{55}$

At first occiderit, (killed) was interpreted reasonably, but later a distinction grew up between occidere (to kill) and mortis causam praestare, (to furnish a cause of death) ${ }^{56}$ Only the former was within the scope of the lex Aquilia. The line between occidere and mortis causam praestare was not always drawn in the same place but classical jurists held it was not killing to give a man poison instead of medicine, ${ }^{57}$ or a drug to a woman which she drinks herself and from which she died, ${ }^{58}$ to starve a slave to death ${ }^{59}$ to throw a slave from a bridge or river bank into the water and cause him to drown. ${ }^{60}$ On the other hand, earlier the Republican jurist Alfenus (or his master Servius) had held that when two carts were going up the Capitoline hill, one behind the other, and the first began to slip back and the men holding it up got out of its way of their accord, and it hit the second cart which moved backwards and ran over a slave boy, the boy's owner could sue the men under the lex Aquilia. ${ }^{61}$

This classical restriction of the meaning of occidere is illogical and even absurd for two reasons. First the word does not usually have such a narrow meaning, and nothing in the phrasing of the lex necessitated or even suggested the restriction. Secondly, the jurists did not take occidere so narrowly in other contexts. Thus, the lex Cornelia de sicariis et veneficiis, the statute of 81 B.C. on murder, also used the word occiderit, ${ }^{62}$ but nowhere in the surviving sources is there the slightest sign that a distinction was drawn there between occidere and mortis causam praestare or that occidere was interpreted narrowly.

When killing was treated merely as furnishing a cause of death, no action on the lex Aquilia was allowed but an ad hoc remedy, actio utilis or actio in

55 occiderit, quanti id in eo anno plurimi fuit, tantum aes dare domino damnas esto. D. 9.2.2pr (Gaius 7 ad ed. prov.).

56 Apparently formulated (D. 9.2.7.6.) by Celsus (Consul for the second time in 129 A. D.) ; but it existed at least since Labeo, in the very early Principate (see D. $9.2 .9 \mathrm{pr})$.

57 D. 9.2.7.6.

58 D. 9.2 .9 pr.

59 D. 9.2.9.2.

60 G. 3.219 .

61 D. 9.2.52.2.

62 Collatio $1.3 ; 1.3$; cf. D. $48.8 .1 \mathrm{pr}$. 
factum, was provided by the praetor. The problem is to know why the jurists drew the distinction. Obviously their purpose was to restrict the field of application of the statute while yet allowing the injured owner a remedy. I can offer no satisfactory explanation of their practical motivation.

It is not necessary to linger over the conclusions. I have tried to show by means of a few examples that, at least sometimes, the Roman jurists were more concerned to reach a sensible practical result than to follow the dictates of a rigorous logic, that they were not ivory-tower philosophers but sensible men dealing with contemporary problems of living. Though it may be felt that this diminishes the claims of Roman law to be a system of universal unchanging validity, it must make us accept the Roman jurists as individual human beings. And we must give credit to their sophistication. 